\title{
“CARA A CARA COM A CÉLULA": PROPOSTA DE UM JOGO PARA O ENSINO DE BIOLOGIA CELULAR
}

\section{"FACE TO FACE WITH CELL": A PROPOSED GAME FOR CELL BIOLOGY TEACHING}

\section{“CARA A CARA COM LA CÉLULA": PROPUESTA DE UN JUEGO PARA LA ENSEÑANZA DE BIOLOGÍA CELULAR}

\author{
Maria Emília Oliveira de Carvalho ${ }^{1}$; Gustavo de Barros Silva ${ }^{2}$; Jaqueline Inez de \\ Santana $^{3}$; João Vitor da Silva ${ }^{4}$; Ana Cristina Lauer Garcia ${ }^{5}$
}

DOI: https://doi.org/10.31692/978-65-991061-3-2.118-123

\section{INTRODUÇÃO}

A biologia celular estuda as unidades funcionais dos seres vivos, as células, sendo um importante ramo da biologia. Todavia, por tratar com estruturas microscópicas e submicroscópicas, esta disciplina pode se tornar um desafio para os professores e estudantes, uma vez que a maioria das escolas não possuem recursos que facilitem o ensino, como microscópios e modelos didáticos que tornem menos abstratos os conteúdos trabalhados em sala de aula. Como resultado, muitas vezes as aulas de biologia celular acabam sendo monótonas e desestimulantes para os discentes (OENNING; OLIVEIRA, 2011).

A aplicação de atividades didáticas como os jogos educativos tem sido apontada por diversos autores como uma forma de preencher muitas lacunas deixadas pelo processo de ensino-aprendizagem. Ao mesmo tempo essa prática torna as aulas mais atrativas e motivadoras, servindo como instrumento de apoio para auxiliar e reforçar os conteúdos já estudados, favorecendo o trabalho em grupo, a socialização de conhecimentos prévios e sua utilização para a construção de informações novas e mais elaboradas (KISHIMOTO, 1994; CAMPOS, 2003).

\footnotetext{
${ }^{1}$ Licenciatura em Ciências Biológicas, Universidade Federal de Pernambuco, Centro Acadêmico de Vitória, emiliaoliveira01@ hotmail.com

${ }^{2}$ Licenciatura em Ciências Biológicas, Universidade Federal de Pernambuco, Centro Acadêmico de Vitória, gustavo-456@hotmail.com.br

${ }^{3}$ Licenciatura em Ciências Biológicas, Universidade Federal de Pernambuco, Centro Acadêmico de Vitória, jaquelinesantanaa18@hotmail.com

${ }^{4}$ Licenciatura em Ciências Biológicas, Universidade Federal de Pernambuco, Centro Acadêmico de Vitória, jv3160339@gmail.com

5 Doutora em Genética, Universidade Federal de Pernambuco, Centro Acadêmico de Vitória, alauergarcia@yahoo.com.br
} 
Aqui apresentamos a proposta de um jogo didático intitulado "Cara a cara com a célula" o qual pode ser utilizado no ensino médio como facilitador do processo de ensinoaprendizagem de conceitos estudados em biologia celular.

\section{FUNDAMENTAÇÃO TEÓRICA}

A biologia celular é um dos primeiros temas estudados na disciplina de biologia no ensino médio. Esta é uma área de difícil compreensão pelos estudantes, que alegam ser complicado compreender os assuntos trabalhados, os quais são considerados, muitas vezes, abstratos e distantes do cotidiano dos discentes (SILVEIRA, 2013). Somado a isso, as aulas geralmente são teóricas, mantendo o aluno na passividade, apenas recebendo os conteúdos sem interagir com eles (ROSSETTO, 2010). Essa forma de ensino é comumente considerada desmotivadora pelos alunos, gerando a necessidade de novos encaminhamentos metodológicos pelo professor (ZUANON et al, 2010).

A fim de resgatar o interesse dos estudantes em aprender, as atividades lúdicas, como jogos educativos, têm sido apontadas como alternativas valiosas para tornar as aulas de biologia mais atrativas e dinâmicas. O jogo permite que o aluno brinque e aprenda simultaneamente, sendo uma forma de auxiliar a aprendizagem e de reforço dos conteúdos estudados (JANN; LEITE, 2010). A utilização de jogos no processo de ensino-aprendizagem também é incentivada pelas Orientações Curriculares para o Ensino Médio no Brasil, a qual defende que os jogos estimulam os estudantes ao mesmo tempo que possibilitam aos professores desenvolverem os conteúdos escolares de forma prazerosa e participativa, levando os discentes a uma maior apropriação dos assuntos estudados (BRASIL, 2006). Os jogos didáticos são ferramentas que complementam as aulas teóricas e práticas agregando motivações e desafios para os estudantes (SOSSELA; CROCETTI, 2013).

\section{METODOLOGIA}

Esta é uma pesquisa qualitativa na qual foi confeccionado um jogo denominado "Cara a cara celular", o qual foi produzido com materiais acessíveis, duráveis e de baixo custo, pensando na realidade das escolas públicas atuais. Para sua confecção foram utilizados os seguintes materiais: papelão, caixas de sabonete, cartolina branca, cartolina dupla face (azul, vermelha e verde), fita adesiva transparente e branca, fita isolante branca, cola quente e pistola, palitos de churrasco e cartas impressas. 
Primeiramente foram confeccionadas 20 cartelas em papel cartão (cada uma com 7 x 5 $\mathrm{cm}$ ) compostas pela imagem de uma estrutura ou tipo celular, com sua respectiva identificação. Para cada cartela foram produzidas três cópias, totalizando 60. Cada conjunto de cartelas foi aderido a uma cartolina dupla face em cores diferentes (azul, vermelha e verde).

Foram produzidos dois tabuleiros com caixas (com dimensão de $32 \times 27$ × $8,5 \mathrm{~cm}$ ) recobertas por cartolina branca. Para o acabamento foram utilizadas fita isolante branca e fita durex transparente. Cada tabuleiro foi dividido internamente com três barreiras, sendo gerados quatro espaços de $8 \mathrm{~cm}$. Entre as barreiras foram colocados palitos de churrasco, atravessando a caixa horizontalmente, para dar suporte as cartelas e permitir sua movimentação durante o jogo. Uma caixa produzida com embalagem de sabonete e recoberta com cartolina dupla face verde, foi aderida em frente a cada tabuleiro para abrigar as cartelas durante a dinâmica do jogo. Para armazenar o terceiro lote de cartelas (na cor verde), foi confeccionada uma caixa, também com embalagem de sabonete, recoberta com cartolina branca e fitas adesivas.

\section{RESULTADOS E DISCUSSÕES}

O jogo "Cara a cara com a célula" (Figura 1) foi planejado para ser um material de apoio didático para as aulas de biologia celular no ensino médio. O jogo poderá ser utilizado pelo professor como forma de revisão de conteúdo ou até mesmo como forma avaliativa. O professor deverá acompanhar os estudantes durante o jogo e, a partir das perguntas elaboradas e das respostas dadas, poderá observar quais as principais dificuldades dos estudantes em relação aos assuntos ensinados, a fim de aprimorar esse conhecimento posteriormente.

O jogo será sempre entre dois jogadores, um jogador ficará com o tabuleiro com as cartelas vermelhas e o outro com o tabuleiro com as cartelas azuis. Os jogadores devem estar sentados um de frente para o outro, a fim de evitar a visualização de suas cartelas pelo oponente. Cada jogador deverá sortear uma cartela verde, a qual ficará no suporte em frente ao seu tabuleiro. Cada jogador deverá fazer perguntas ao adversário para tentar adivinhar a cartela sorteada. Será permitido uma única pergunta por jogador a cada rodada e, a seguir, a vez será passada ao seu adversário. A cada pergunta o adversário só poderá responder "sim" ou "não". De acordo com as respostas os jogadores deverão ir abaixando as cartelas que não se enquadram com resposta dada pelo seu adversário. Por exemplo, se o jogador perguntar se a cartela em questão é de uma organela que possui a função de digestão celular e a resposta do seu oponente 
for não, o jogador deverá abaixar a cartela com a imagem do lisossomo, descartando essa possibilidade.

Figura 1. Jogo "Cara a cara com a célula" produzido para o aprendizado da biologia celular. A) Jogo completo. B) Jogo com algumas cartelas abaixadas durante a dinâmica de uma partida.
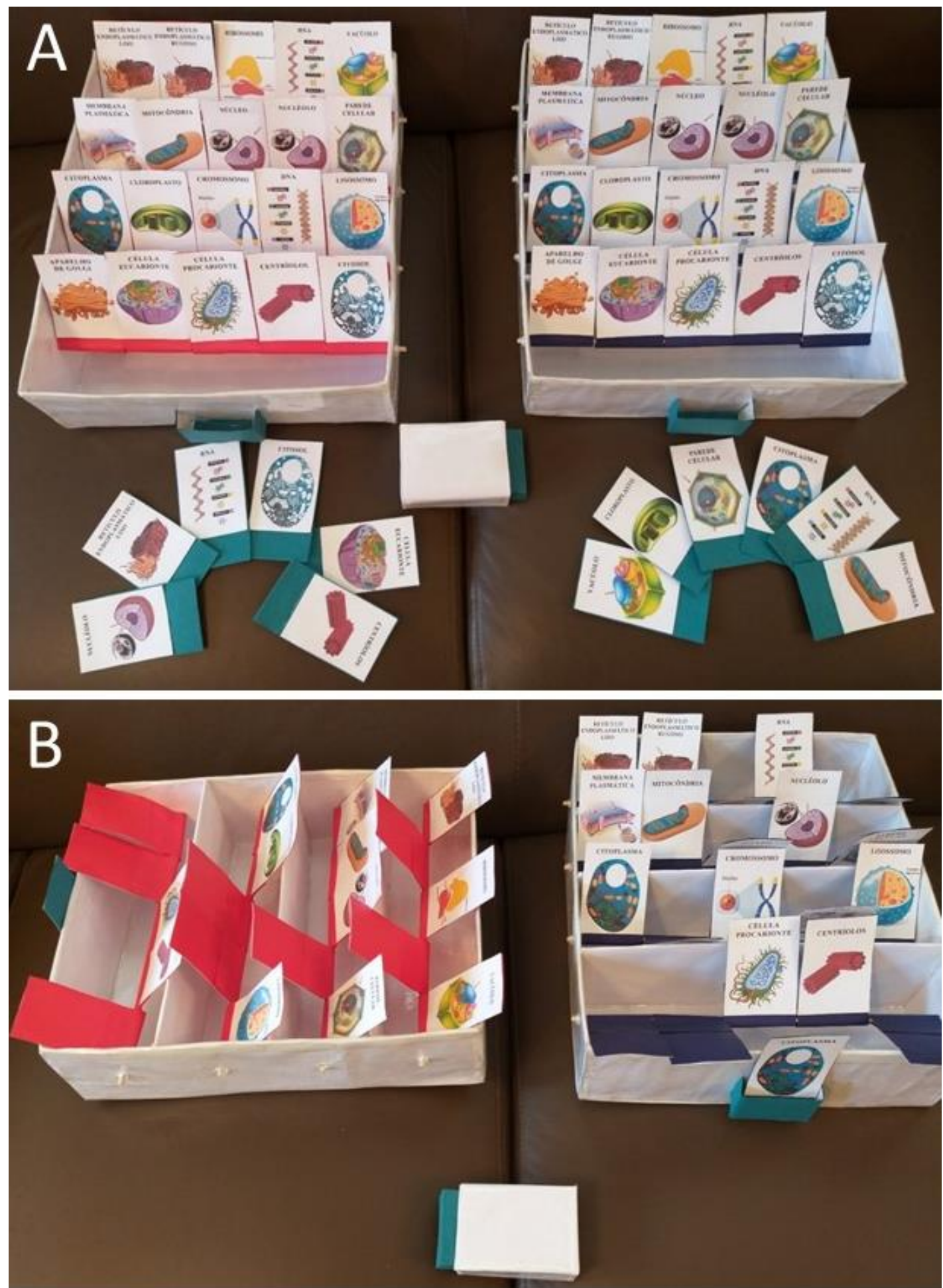

Fonte: Própria (2019) 
Outras regras adicionais incluem o fato de que a primeira pergunta da rodada não poderá eliminar um número grande de cartelas, por exemplo, não poderá ser questionado se a cartela em questão se trata de uma organela, pois assim, descartaria um grande número de cartelas. Não poderão ser feitas perguntas em relação a cor, tamanho ou formato das estruturas presentes nas cartelas. Também não poderão ser feitas perguntas envolvendo o nome da estrutura a ser adivinhada. Serão realizadas cinco partidas, quem vencer a maioria ganhará a disputa. Este jogo também poderá ser disputado por duplas ou em grupos maiores de alunos.

Esse recurso lúdico auxiliará na aprendizagem dos conteúdos de biologia celular, uma vez que os alunos terão que lembrar dos assuntos abordados para poder elaborar as perguntas e responder corretamente aos questionamentos feitos pelo seu oponente. Recursos metodológicos diferenciados tornam o ensino de biologia celular mais dinâmico, fugindo de aulas tradicionais, nas quais o professor é a figura central. Durante o jogo, o aluno desenvolve a iniciativa, a imaginação, o raciocínio, a memória, a atenção, a curiosidade e o interesse, concentrando-se por longo tempo em uma atividade (FORTUNA, 2003).

A partir desta proposta de jogo o aluno pode entender a diferença entre células eucariontes e procariontes e reconhecer as organelas e estruturas celulares encontradas em cada tipo celular. Da mesma forma, poderá compreender a função dos componentes presentes em cada cartela e aprender sobre diferentes componentes celulares.

Muitos autores têm motivado a utilização de jogos didáticos em sala de aula, a fim de contribuir para uma aprendizagem significativa de conteúdos ligados a biologia celular. Os jogos educativos se destacam como eficientes instrumentos envolventes e estimulantes, sendo uma importante alternativa para auxiliar no processo de ensino-aprendizagem (ROSSETTO, 2010; GONÇALVES, 2014). Esta é uma importante estratégia de ensino para a aprendizagem de conceitos abstratos e complexos, favorecendo a motivação, o raciocínio, a argumentação, a interação entre alunos, bem como entre professores e alunos (CAMPOS et al, 2003).

\section{CONCLUSÕES}

O jogo apresentado pode ser utilizado por professores do ensino médio para auxiliar nas aulas de biologia celular, sendo uma ferramenta alternativa para uma aprendizagem mais eficaz deste tema pelos discentes.

\section{REFERÊNCIAS}


BRASIL, MEC, SEB. Orientações Curriculares para o Ensino Médio. Ciências da Natureza, Matemática e suas Tecnologias. Brasília: MEC, SEB, 2006.

CAMPOS, L.M.L.; BORTOLOTO, T.M.; FELÍCIO, A.K.C. A Produção de jogos didáticos para o Ensino de Ciências e Biologia: uma proposta para favorecer a aprendizagem. Cadernos dos Núcleos de Ensino. São Paulo, Brasil. p. 47- 60, 2003.

FORTUNA, T. R. Jogo em aula: recurso permite repensar as relações de ensino-aprendizagem. Revista do professor. Porto Alegre, 2003. v. 19. n. 75. p. 15-19, 2003.

GONÇALVES, R. R.; MARTELO, A. R.; EPPLE, B.; LAUERENCE, C.; DESBESSEL, J.; POST, P. Bingo da Célula: Uma Ferramenta Metodológica para o Ensino de Biologia Celular. Revista Ensino e Pesquisa. v. 12. n. 1. p. 28-47, 2014.

JANN, P. N.; LEITE, M. F. Jogo do DNA: um instrumento pedagógico para o ensino de ciências e biologia. Ciências \& Cognição. v.15. n. 1. p. 282-293, 2010.

KISHIMOTO, T. Jogo, Brinquedo, Brincadeira e Educação. São Paulo: Cortez, 1994.

OENNING, V.; OLIVEIRA, J.M.P. Dinâmicas em sala de aula: envolvendo os alunos no processo de ensino, exemplo com os mecanismos de transporte da membrana plasmática. Revista Brasileira de Bioquímica e Biologia Molecular. Paraná, n. 01, 2011.

ROSSETTO, E. S. Jogo das organelas: o lúdico na Biologia para o Ensino Médio e Superior. Revista Iluminart. Sertãozinho, 2010. v. 1. n. 4. p. 118-123, 2010.

SILVEIRA, M. L. Dificuldades de aprendizagem e concepções alternativas em biologia: a visão de professores em formação sobre o conteúdo de citologia. Natal, 2013. 197 p. Dissertação (Ensino de Ciências Naturais e Matemática). Centro de Ciências Exatas e da Terra, UFRN, 2013.

SOSSELA G. S.; CROCETTI, S. Jogos como facilitadores do Ensino de Biologia. Cadernos PDE. Paraná. v. 1. 2013.

ZUANON, A. C. A.; DINIZ, R. H. S.; NASCIMENTO, L. H. Construção de jogos didáticos para o ensino de Biologia: um recurso para integração dos alunos à prática docente. Revista Brasileira de Ensino de Ciência e Tecnologia. Minas Gerais, 2010. v. 3. n. 3. p. 49-59, 2010. 